\title{
Assessment of mathematical models of drying of jabuticaba peels through performance indicators
}

Avaliação de modelos matemáticos de secagem de casca de jabuticaba por meio de indicadores de desempenho

\author{
D. S. C. Soares ${ }^{1}$; J. T. S. Santos ${ }^{1}$; L. A. L. C Lima ${ }^{1}$; T. P. Nunes ${ }^{1}$; A. M. Oliveira \\ Júnior $^{*}$ \\ ${ }^{I}$ Departamento de Tecnologia de Alimentos, Universidade Federal de Sergipe,49100-000, São Cristóvão-Sergipe, \\ Brasil
}

amartins.junior@gmail.com

(Recebido em 31 de janeiro de 2016; aceito em 01 de abril de 2016)

\begin{abstract}
Brazil is a country with a huge diversity of native fruits, and one of them is jabuticaba. The jabuticaba peel is the main part of the fruit due to the high level of bioactive compounds besides fibers and minerals. Therefore, it is necessary to use this residue that can be reused for several purposes, such as extraction of anthocyanins for production of natural food coloring and phenolics compounds which can be used to produce extracts with antioxidants properties. Drying technology is applied with the objective of increasing the shelf life of the jabuticaba skin which has a high level of water. In the present work, an evaluation of mathematical drying models through performance indicators which were accuracy factor $\left(\mathrm{A}_{\mathrm{f}}\right)$, bias factor $\left(\mathrm{B}_{\mathrm{f}}\right)$, root mean square error (RMSE) and standard error of prediction (\%SEP) was done for studying the drying kinetic of the jabuticaba pell. The drying process was conducted in a convective tray dryer at $43{ }^{\circ} \mathrm{C}$ for 352 min with final moisture content of $3.64 \%$ in dry basis. According to the results, the two terms model and the Midilli model were the ones that better fitted the experimental data, and the Page model was the third one. However, the convenience of using the Page model is due to the computational and numerical advantage because it is needed to estimate only two parameters.

Keywords: Drying models, jabuticaba peel, performance indicators
\end{abstract}

O Brasil é um país com ampla diversidade de frutas nativas, dentre elas a jabuticaba. A casca de jabuticaba é uma parte importante do fruto que possui alto teor de compostos bioativos, além de fibras e minerais. É necessário o aproveitamento deste resíduo que pode ser utilizado para inúmeros fins como, por exemplo, a extração de antocianinas para a produção de corante natural para alimentos e compostos fenólicos que podem ser utilizados para a produção de extratos com propriedades antioxidantes. Com o intuito de aumentar a vida útil deste resíduo que possui um alto teor de água, aplica-se a tecnologia de secagem. No presente trabalho, foi realizada a avaliação de modelos matemáticos de secagem através de indicadores de desempenho (fatores de precisão $\left(\mathrm{A}_{\mathrm{f}}\right)$ e de ruído $\left(\mathrm{B}_{\mathrm{f}}\right)$, raiz do erro quadrático médio $(\mathrm{REQM})$ e erro padrão de predição (\%SEP) para o estudo da cinética de secagem da casca de jabuticaba. A secagem foi conduzida em um secador convectivo de bandejas à $43{ }^{\circ} \mathrm{C}$ por $352 \mathrm{~min}$ obtendo-se a umidade final de 3,64\% em base seca. De acordo com os resultados obtidos, o modelo de dois termos e o de Midilli foram os que melhor se ajustaram aos dados experimentais, seguido do modelo de Page. No entanto, a facilidade do modelo de Page surge como vantagem computacional e numérica já que necessita da estimativa de apenas dois parâmetros.

Palavras-chave: Modelos de secagem, casca de jabuticaba, indicadores de desempenho

\section{INTRODUCTION}

The jabuticaba tree belongs to the Myrtacea family, and it is native from the Central, South and South East of Brazil. The jabuticaba fruit is normally found in markets and supermarkets in every part of Brazil, and it is very consumed in natura [1]. Jabuticaba is an important source of nutrients and bioactive compounds [2]. Due to these characteristics and its flavor, the jabuticaba has been used to produce other products, such as juice, jam, vinegar, liqueurs and wines [3].

Usually, after the fruit processing, the jabuticaba peels and seeds are wasted. They represent $50 \%$ of the entire fruit due to that fact it is necessary the utilization of those parts to add value and 
avoid the fruit waste [4]. The jabuticaba peel is a source of anthocyanins which are flavonoids that are responsible for the dark color of the fruit. These pigments have compounds with antioxidant and anti-inflammatory properties, besides the antimicrobial activity [5].

Despite the high market potential, the jabuticaba does not have a great economic value because of its perishability [3]. The reduction of water content in fruits using drying process is a way to increase their shelf life [6]. The drying process reduces the moisture content and the water activity of the food, so that the microbial growing, enzymatic activity, and chemical reactions are reduced. With this, the shelf life is increased, and the transport and storage costs are decreased [7].

Mathematical models have been used to simulate drying curves in different conditions to have a higher control of the drying processes [8]. Drying models are used for new systems projects or to improve existent projects, or even control the process conditions [9]. The modeling has several advantages, for example, the reduction of experiments and costs related to the drying process [10].

A number of models are used to describe the drying process of many food products, such as vegetables, cheeses, and fruits [9]. These models can be theoretical, semi-theoretical and empirical. The semi-theoretical models have been widely used due to its usage convenience. Some of them are Page, Henderson and Pabis, Modified Henderson-Pabis, modified Page, Midilli, Two Terms, Thompson, Wang and Singh, and others [11].

In this present work, the study of the drying kinetic of jabuticaba peel in tray dryer was done with the evaluation of five mathematical models of drying using the following performance indicators: accuracy factor (Af), bias factor (Bf), root mean square error (RMSE) and standard error of prediction (\%SEP).

\section{MATERIAL E METHODS}

\subsection{Experimental Treatment}

The work was done at the pilot plant of the food technology department (DTA) located at the Federal University of Sergipe (UFS). The jabuticabas were purchased from a local market in Estancia, SE, and it was transported to the laboratory under cooling in a thermal box with ice. After that, the fruits were sanitized in active chlorine solution at $200 \mathrm{ppm}$ for $10 \mathrm{~min}$, and then, the fruits were washed in active chlorine solution at $3 \mathrm{ppm}$ for $5 \mathrm{~min}$. Then, the peels were separated manually from the pulp. The pulp was stored in a conventional freezer at $-18^{\circ} \mathrm{C}$ (Model CVU18, Consul), and the peels were used in the drying process.

The drying of the peels was conducted at the tray dryer (Desidratador Pardal) at $43{ }^{\circ} \mathrm{C}$ for 5,8 $\mathrm{h}$. The temperature of the drying process was determined according to the literature to preserve the bioactive compounds. In addition, the time of processing was determined through previous experiments until the jabuticaba peel was completely dried. In order to make drying kinetic, samples were collected in time intervals to determine the moisture content. It was used moisture analyzer (Model MOC-63U, Shimadzu) to determine the moisture content of the samples.

\subsection{Mathematical Treatment}

With the objective of determining the drying kinetics of jabuticaba peel and evaluating the mathematical models of drying, the moisture content ratio of the experimental data was determined using the equation 1.

where:

$$
R U=\frac{\left(U(t)-U_{e q}\right)}{\left(U_{i}-U_{e q}\right)}
$$

$\mathrm{RU}$ is the moisture content ratio;

$\mathrm{U}(\mathrm{t})$ consists in the moisture content at any time $\mathrm{t}$ (dry basis);

$\mathrm{U}_{\text {eq }}$ is the equilibrium moisture content (dry basis) and;

$\mathrm{U}_{\mathrm{i}}$ is the initial moisture (dry basis). 
The experimental drying curves were fitted with the models described in Table 1. It was used the software STATISTICA $®$ version 11.0 for Windows to estimate the parameters. The nonlinear regression analysis was done using Levenberg-Marquardt method and least squares as the loss function.

Table 1: Mathematical models of drying.

\begin{tabular}{cc}
\hline Mathematical Models & Equations \\
\hline Page Model & $U=\exp \left(-k \cdot t^{n}\right)$ \\
Henderson and Pabis Model & $U=a \cdot \exp (-k \cdot t)$ \\
Newton Model & $U=\exp (-k \cdot t)$ \\
Midilli Model & $U=a \cdot \exp \left(-k \cdot t^{n}\right)+b \cdot t$ \\
Two Terms Model & $U=a \cdot \exp \left(-k_{0} \cdot t\right)+b \cdot \exp \left(-k_{1} \cdot t\right)$ \\
\hline
\end{tabular}

The evaluation of the model which better fitted to the experimental data was done using performance indicators (Table 2). The software Excel® version 2007 for Windows was used for the data treatment.

Table 2: Performance indicators of the mathematical models.

\begin{tabular}{cc}
\hline Performance Indicators & Equations \\
\hline Root mean square error (RMSE) & $R M S E=\sqrt{\frac{\sum(\text { obs }- \text { pred })^{2}}{n}}$ \\
Standard error of prediction $(\% \mathbf{S E P})$ & $\% S E P=\frac{100}{\text { mean obs } \sqrt{\frac{\sum(\text { obs }- \text { pred })^{2}}{n}}}$ \\
Bias factor $\left(\mathbf{B}_{\mathbf{f}}\right)$ & $B_{f}=10 \frac{\sum \log \left(\frac{\text { pred }}{n}\right)}{n}$ \\
Accuracy factor $\left(\mathbf{A}_{\mathbf{f}}\right)$ & $A_{f}=10 \frac{\Sigma \mid \log \left(\frac{\text { pred }}{n}\right) !}{n}$ \\
\hline
\end{tabular}

\section{RESULTS AND DISCUSSION}

Figure 1 represents the drying kinetics of the jabuticaba peel at $43{ }^{\circ} \mathrm{C}$ with the curves predicted by the models and the experimental data. The jabuticaba peel had $166.14 \%$ of initial moisture content in dry basis and after drying, the final moisture content was $3.64 \%$ in dry basis. As it can be seen in Figure 1, the drying process occurred predominantly at the decrescent rate where the drying rate decreases when the moisture content of the product reduces. This result was observed in the study conducted by Lahsasni et al. (2004) [12] during the drying of prickly pear fruit (Opuntia ficus indica) at different temperatures.
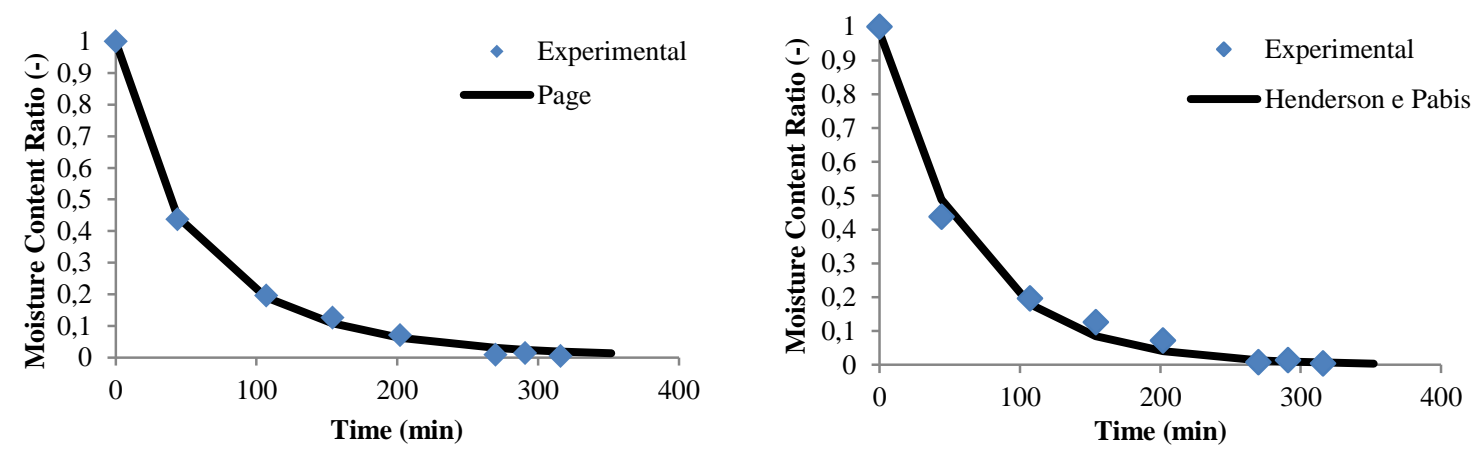
(a)

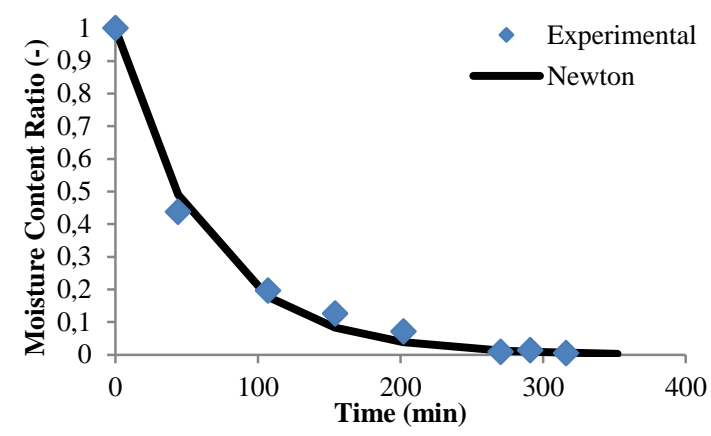

(c) (b)

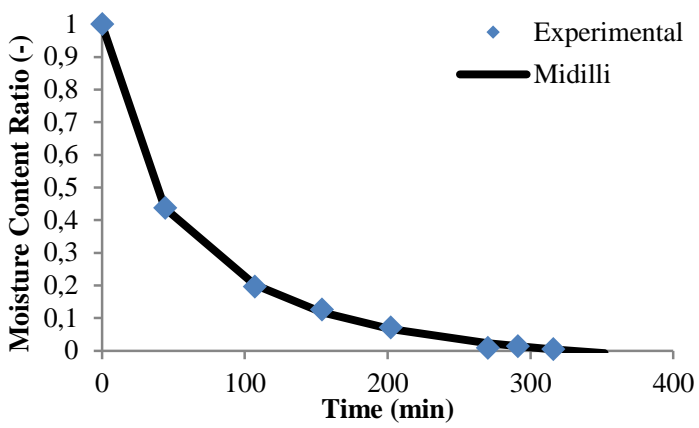

(d)

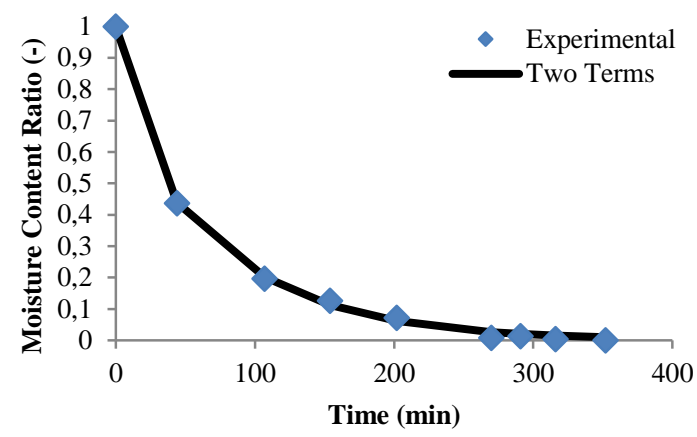

(e)

Figure 1: Graphical representation of the observed and predicted data. (a) Page Model; (b) Henderson and Pabis Model; (c) Newton Model; (d) Midilli Model; (e) Two Terms Model.

The coefficients of determination of the predicted and experimental data were: $0.9985,0.9995$, 0.9936, 0.9936, and 0.9991 for Page model, Midilli model, Newton model, Henderson and Pabis model and two terms model, respectively. According to the coefficients of determination, the models used in this study had a good adjustment to the experimental data. However, the performance indicators were used to analyze the best model to represent the drying process at the studied condition. Table 3 shows the models constants estimated by linear regression.

The performance indicators used in this work were described by Ross (1996) [13]. The RMSE indicator compares the observed data to the predicted data so that the best model should have the reduced value for this indicator. On the same way, the value of the standard error of prediction (\%SEP) should also be reduced to indicated the good correlation between the experimental and predicted values because this indicator analyzes the residual of the models. The accuracy factor $\left(\mathrm{A}_{\mathrm{f}}\right)$ determines the average difference of the experimental and predictive data, consequently, its increase indicates a low precision of the model. Finally, bias factor $\left(\mathrm{B}_{\mathrm{f}}\right)$ represents the perfect agreement between the experimental and predicted data, being $\mathrm{B}_{\mathrm{f}}=1$. The results can be found in Table 4.

Table 3: Parameters determined by the drying models.

\begin{tabular}{ccccccc}
\hline & \multicolumn{7}{c}{ Parameters } \\
\cline { 2 - 7 } Mathematical Models & $\mathbf{k}$ & $\mathbf{n}$ & $\mathbf{a}$ & $\mathbf{b}$ & $\mathbf{k}_{\mathbf{0}}$ & $\mathbf{k}_{\mathbf{1}}$ \\
\hline Page Model & 0.0014 & 0.8075 & - & - & - & - \\
Midilli Model & 0.0028 & 0.7214 & 0.9910 & $-1.54 \times 10^{-6}$ & - & - \\
Newton Model & 0.0003 & - & - & - & - & - \\
Henderson and Pabis & 0.0003 & - & 0.9824 & - & - & - \\
$\quad$ Model & - & - & 0.2437 & 0.7563 & 0.009 & 0.0002 \\
Two Terms Model & - & & & & & \\
\hline
\end{tabular}


Table 4: Results of the performance indicators.

\begin{tabular}{ccccc}
\hline & \multicolumn{4}{c}{ Performance Indicators } \\
\cline { 2 - 5 } $\begin{array}{c}\text { Mathematical } \\
\text { Models }\end{array}$ & RMSE & $\mathbf{A}_{\mathbf{f}}$ & $\mathbf{B}_{\mathbf{f}}$ & \%SEP \\
\hline Page Model & 0.0127 & 1.9886 & 1.8521 & 6.1441 \\
Midilli Model & 0.0067 & 1.4257 & 1.3747 & 3.2596 \\
Newton Model & 0.0264 & 1.4972 & 1.0557 & 12.8002 \\
$\begin{array}{c}\text { Henderson and } \\
\text { Pabis Model }\end{array}$ & 0.0257 & 1.511 & 1.0955 & 12.47 \\
Two Terms Model & 0.0099 & 1.8067 & 1.7035 & 4.8061 \\
\hline
\end{tabular}

According to the Table 4, the Midilli model presented the best results. The Midilli model had lower values for three indicators: RMSE, $\mathrm{A}_{\mathrm{f}}$ and \%SEP with the following results $0.0067,1.4257$ and 3.2596, respectively. It was observed that the Page model also had good results considering its convenience due to the estimation of only two parameters while the Midilli model needs to estimate four parameters. The Page model represents the experimental data in the studied condition with great precision and the advantage of the convenience in the parameter estimation.

\section{CONCLUSION}

The analysis of mathematical models of drying trough the performance indicators was done in the present study. The assessment of the models by using these indicators has an important meaning to give precise results. The Page model had a great correlation with the experimental data for the drying of jabuticaba peels in a tray dryer at $43{ }^{\circ} \mathrm{C}$. This model presented the following results: RMSE: 0.0127; $\mathrm{A}_{\mathrm{f}}: 1.9886$; $\mathrm{B}_{\mathrm{f}}: 1.8521$; \%SEP: 6.1441. Midilli and two terms model also had reasonable results for the performance indicators. Nevertheless, the Page model has the advantage of simplicity due to the estimation of only two parameters.

\section{ACKNOWLEDGEMENTS}

To the Federal University of Sergipe for the infrastructure and the National Council for Scientific and Technological Development $(\mathrm{CNPq})$ for the financial support and scholarships.

\section{REFERENCES}

1. Leite-Legatti AV, Batista AG, Dragano NRV, Marques AC, Malta LG, Riccio MF, Eberlin MN, Macahado ART, Carvalho-Silva LB, Ruiz ALTG, Carvalho JE, Pastore GM, Maróstica Júnior MR. Jaboticaba peel: Antioxidant compounds, antiproliferative and antimutagenic activities. Food Res Int. 2012 Nov; 49(1):596-603, doi: 10.1016/j.foodres.2012.07.044

2. Wu SB, Long C, Kennelly EJ. Phytochemistry and health benefits of jaboticaba, an emerging fruit crop from Brazil. Food Res Int. 2013 Nov;54(1):148-159, doi: 10.1016/j.foodres.2013.06.021

3. Inada KOP, Oliveira AA, Revorêdo TB, Martins ABN, Lacerda ECQ, Freire AS, Braz BF, Santelli RE, Torres AG, Perrone D, Monteiro MC. Screening of the chemical composition and occurring antioxidants in jabuticaba (Myrciaria jaboticaba) and jussara (Euterpe edulis) fruits and their fractions. J Funct Food. 2015 Jun;17:422-433, doi: 10.1016/j.jff.2015.06.002

4. Lima AJB, Corrêa AD, Alves APC, Abreu CMP, Dantas-Barros AM. Caracterização química do fruto jabuticaba (Myrciaria cauliflora Berg) e de suas frações. Arch Latinoam Nutr. 2008 Nov; 58(4):416421.

5. Silva MC, Souza VB, Thomazini M, Silva ER, Smaniotto T, Carvalho RA, Genovese MI, FavaroTrindade CS. Use of the jabuticaba (Myrciaria cauliflora) depulping residue to produce a natural pigment powder with functional properties. Food Sci Technol. 2014 Sep;55(1):203-209, doi: 10.1016/j.lwt.2013.08.026 
6. Silva WP, Rodrigues AF, Silva CMDPS, Castro DS, Gomes JP. Comparison between continuous and intermittent drying of whole bananas using empirical and diffusion models to describe the processes. $\mathrm{J}$ Food Eng. 2015 Dec;166:230-236, doi: 10.1016/j.jfoodeng.2015.06.018

7. Monteiro RL, Carciofi BAM, Laurindo JB. A microwave multi-flash drying process for producing crispy bananas. J Food Eng. 2016 Jun;178:1-11, doi: 10.1016/j.jfoodeng.2015.12.024.

8. Bezerra CV, Silva LHM, Corrêa DF, Rodrigues AMC. A modeling study for moisture diffusivities and moisture transfer coefficients in drying of passion fruit peel. Int J Heat Mass Tran. 2015 Jun;85:750755, doi: 10.1016/j.ijheatmasstransfer.2015.02.027

9. Shi Q, Zheng Y, Zhao Y. Mathematical modeling on thin-layer heat pump drying of yacon (Smallanthus sonchifolius) slices. Energ Convers Manage. 2013 Jul;71:208-216, doi: 10.1016/j.enconman.2013.03.032

10. Menges HO, Ertekin C. Mathematical modeling of thin layer drying of Golden apples. J Food Eng. 2006 Nov; 77(1):119 - 125, doi: 10.1016/j.jfoodeng.2005.06.049

11. Aregbesola OA, Ogunsina BS, Sofolahan AE, Chime NN. Mathematical modeling of thin layer drying characteristics of dika (Irvingia gabonensis) nuts and kernels. Niger Food J. 2015 May;33:83-89, doi: 10.1016/j.nifoj.2015.04.012

12. Lahsasni S, Kouhila M, Mahrouz M, Jaouhari JT. Drying kinetics of prickly pear fruit (Opuntia ficus indica). J Food Eng. 2004 Feb; 61(2):173-179, doi: 10.1016/S0260-8774(03)00084-0

13. Ross T. Indices for performance evaluation of predictive models in food microbiology. J Appl Bacteriol. 1996 Mar;81:501-508, doi: 10.1111/j.1365-2672.1996.tb03539.x 